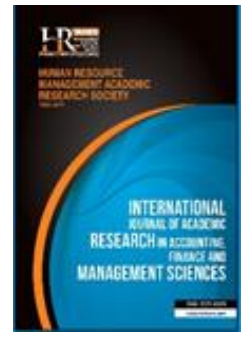

International Journal of Academic Research in Accounting, Finance and Management Sciences

Vol. 10, No.2, April 2020, pp. 87-99

E-ISSN: 2225-8329, P-ISSN: 2308-0337

(c) 2020 HRMARS

www.hrmars.com

To cite this article: Desiyanti, R., Md Kassim, A. A. (2020). Financial Literacy on Business Performance: The Moderating Effect of Religiosity Among SMEs In Sumatera, Indonesia, International Journal of Academic Research in Accounting, Finance and Management Sciences 10 (2):87-99.

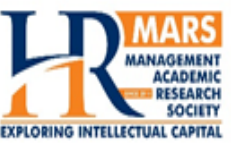

\title{
Financial Literacy on Business Performance: The Moderating Effect of Religiosity Among SMEs In Sumatera, Indonesia
}

\author{
Rika Desiyanti ${ }^{1}$, Aza Azlina Md Kassim ${ }^{2}$ \\ ${ }^{1,2}$ Faculty of Economics and Business Bung Hatta University, Faculty of Business and Accountancy, Universiti Selangor \\ ${ }^{1}$ E-mail: rikadesiyanti@bunghatta.ac.id (Corresponding author), ${ }^{2} E$-mail:aza_azlina@unisel.edu.my
}

\begin{abstract}
Business performance represents how well the company can make use of business assets and generate receivable. Business performance is a result of company activities or investments over a given period. It is a specific business goal achievement measured against standards, completeness, and costs. The business performance was the result of corporate strategies employed to achieve market-oriented. In the years between 2012 and 2014, the Enterprise Survey (2015) has conducted a financial survey of Indonesian private sector/micro, and the result was lower-middle-income economies and small firms (5-19 employees) had the worst performance. The owners of SMEs should manage their financial business effectively to achieve good business performances. A low level of financial literacy causes a bad effect on business performances. This paper aims to analyze the influence of financial literacy on SME's business performance with religiosity as the moderating variable. A questionnaire survey has been distributed among SMEs owners in Sumatera, Indonesia. From 387 respondents as the samples of this study, the result shows that financial literacy affects business performance, religiosity affects business performance and religiosity strengthens the relationship between financial literacy and business performance.
\end{abstract}

Key words

Business Performance, Financial Literacy, Religiosity.

Received: 10 May $2020 \quad$ (c) The Authors 2020

Revised: 10 Jun 2020 Published by Human Resource Management Academic Research Society (www.hrmars.com)

Accepted: $\quad 30$ Jun 2020 This article is published under the Creative Commons Attribution (CC BY 4.0) license. Anyone may Published Online: $\quad 08 \mathrm{Jul} 2020$ reproduce, distribute, translate and create derivative works of this article (for both commercial and non-commercial purposes), subject to full attribution to the original publication and authors. The full terms of this license may be seen at: http://creativecommons.org/licences/by/4.0/legalcode

\section{Introduction}

Business performance is the ways or methods a company uses in reaching its goals. A company may use all the related data to find better methods. Developing effective methods for reaching goals has been around since business first began. Business performance management was developed as a way to streamline this monitoring process and develop a more efficient way of achieving corporate goals. Good business performance related to financial literacy. Low levels of financial literacy might lead to unprofitable investment, bad business performance, and bankruptcy. Therefore, it is very important to examine the influence of SME owners' financing literacy on business performance. Anggraeni (2015) posits that the ability to manage the finances of the business is fundamental in enhancing business performance. SME's owners need financial literacy to manage their business, which may be derived from several sources, to support the maintenance and progress of their business. Financial literacy was one of the major factors associated with the SME's business performance. Financial literacy will affect business performance.

Financial literacy is part of basic human needs to achieve good business performance. Mostly financial problems caused by incorrect financial management. Several things influence financial literacy among others; no savings, unappropriate investment, the use of excessive debt, lack of financial planning, 
and more investigates religiosity that strengthens the relationship between financial literacy and business performance. Islamic Finance is currently growing rapidly where Islamic financial institutions offer financial goods and services based on Islamic jurisprudence.

Islamic finance is expected to be a solution for financial practices, that lead to may sir, usury, and gharar. Sharia finance has a low growth business for the majority of the Indonesian Moslem. Islam is a religion that concerns literacy. The Qur'an mentions the verses relating to wealth and finances, such as Zakat, Shodaqah, endowment, and Hajj, which require considerable funding. Financial planning is required for Moslems. Islam as a religion that regulates all aspects of a life-giving direction. In the case of receivables or income, consumption, savings, investments, property management, and all financial aspects related to finance. In Islam, the attitude of the religiosity reflects one's relationship with Allah. Moslem attitudes should not be stingy, selfish, and dishonest in conducting business and financial activities. The life of a Muslim should survive well in the world and the day after. Religiosity may help increase a person's selfcontrol. A person who is obedient in carrying out his religious will be able to control himself. Religion can control human behavior.

According to Sahlan (2011) one's religiosity is manifested in his/her life. Religious activity occurs when a person conducts rituals (worship), other activities are driven by a supernatural power. It is concerning activities that appear and can be seen with the eye. Based on this attitude, people do an activity following the provisions of the religion and obey God's commandments on the effect of religiosity particularly on Islamic management and financial literacy towards business performance is still scanty. The research on the interaction between Islam and other management areas is highly demanded. This study incorporates element religiosity as a moderator variable between financial literacy and business performance. Indonesia includes a big Muslim country majority with a population of 216.66 million people or 85 percent of the population (BPS, 2015).

Indonesia, especially the island of Sumatera, is a country with a majority of Moslems population (Trigrunoho et al., 2016). According to the Pew Research Center (2017), a large proportion of Moslems around the world (62 percent) reside in Indonesia, India, Pakistan, Bangladesh, Iran, and Turkey. Furthermore, Gallup's survey in 2010 shows that Indonesia is one of the greatest Moslem countries and has a great religious level as well as in the world. Indonesia is a country with a Moslem majority. Therefore, the measurement of religiosity used is adopted from an Islamic perspective. Nowadays, there is a high interest in the research of Moslem religiosity as a field of empirical investigation. Therefore, some considerations based on Islam are included (Adawiyah \& Pramuka, 2017).

Religiosity as a moderating variable might strengthen the relationship between financial literacy and business performance. It is necessary to investigate the potential of SMEs to improve their financial literacy and business performance. Islam posits its followers to do business and enjoy the benefits/business performance. Moslem entrepreneurs have to be honest and trustworthy in their business (De Run et al. 2010). Islam teaches its people to study and widen their knowledge as well as skills of finance. It strengthens the relations between financial literacy on business performance.

\section{Literature Review and Hypothesis Development}

\subsection{Business Performance}

Business performance is an achievement as the result of individual work and a company in a given period. It associated with a specific value or standard size of the company's work. Achievement of the objectives organization or whether that's been applied. In previous studies, the SME's business performance was measured using financial and non-financial calculations (Mantok et al., 2019; Kukuh et al., 2010). Traditional financial measures relating to non-financial measures continue to be widely used by various studies, to measure business performance. For example, Alhadab \& Own (2017), Samail et al. (2018), Jao et al. (2020) use two proxies for performance that are return on assets (ROA) and return on equity (ROE). (Budiharjo, 2019) use proxy for financial performance that are total asset turn over (TATO).

The business performance of SMEs is a challenge for all businesses around the world. SME's business performance has been defined in different ways in the literature. Related parties always want to see good business performance in their business activities (Harash et al., 2014). Thrikawala (2011) defines business performance as how well the company can make use of business assets and generate receivable. In modern 
literature defines business performance as a result of company activities or investment over a given period. The business performance also defined as a specific business goal achievement measured against standards, completeness, and cost (Thrikawala, 2011). The business performance was the result of corporate strategies to employ to achieve market-oriented and finance (Harash et al., 2014). In the study, business success is sometimes used to refer to the company's business performance.

SMEs often play an important role in increasing the country's economy and lead to the development of the global economy. This puts the business performance as one important part for SMEs in which management is concerned. Business performance acts as an indicator in determining whether the business has achieved its target for that particular time. The business performance was the outcome of corporate business performance is the result of a corporate strategy that works with market-oriented and financial. (Harash et al., 2014).

The companies success rate in the SME sector measured through business performance. Researchers have previously sought to give a clear definition of business performance but they have not reached an agreement over the general definition. Especially about some aspects of the terminology problem, a basic level of analysis, and conceptual assessment. Findings from previous studies do not give a general definition of business performance (Harash et al., 2014). Mutegi et al. (2015) define the business performance of SMEs as the outcome of work achieved by individuals and adaptation to the individual tasks or roles in a company in a given period. It is associated with a value or standard of the company's work. Based on the findings of the previous study, the business performance of the special area of the company includes the following three outcomes: (i) financial business performance (profit, return on total assets, return on total investment, etc.); (ii) a shareholder return (the economic value added), and (iii) nonfinancial business performance example market business performance (sales,), etc; and (iii) a shareholder return (the economic value added).

Financial literacy needs to be done to improve the company's business performance and have an easy-to-understand indicator. The indicators as the company's growth, are the company's total receivable (sales), total orders, and cash position. The best financial literacy of entrepreneurs is important to make the right decisions for the company (Muraga, 2015). The owner/business manager associated with complex financial decisions makes and strategically links to the success of business objectives.

Pellissier (2014) stated that most researchers propose business performance as to multidimensional measure. There are four dimensionalities (i.e., business growth, profit, customer image and loyalty, and product service innovation) that were hypothesized to validate business performance measures in the context of South Africa. Their research shows that non-financial dimensions (i.e., image and customer loyalty, and product service innovations) are invalid dimensions for measuring business performance, while the other two dimensions (i.e., business growth and profitability) indicates a high level of correlation and is valid in measuring performance. This indicates that business growth is connected with profitability. Growth profitability is a business major concern. The profitability remains the key measure of business performance in the South African banking sector. Parameters such as customer loyalty and innovation are not considered essential to the size of business performance, although this can suppress the issue for the Bank.

\subsection{Financial literacy}

Financial literacy is the knowledge and ability in organizing personal and business finance. Intelligence and the capabilities of financial management are important aspects of life. Financial literacy is the knowledge and ability in organizing finance personal and business. Knowledge intelligence and capabilities of financial management are one of the important things (Boehnke et al., 2018). Financial literacy may prevent people from financial problems. Financial literacy shows the ability to give information and good reasoned for economic and decisions in their finance (Rosacker \& Rosacker, 2016). Recent empirical works focus on the analysis of financial (Brown et al., 2016; Fernandes et al, 2014; Miller et al., 2015; Kaiser \& Menkhoff, 2016; Grohmann, 2015).

Mihalcová et al. (2014) and Pružinský et al. (2014) state that financial literacy is not an absolute statement. It is a continuity of the capability that influenced by age, families, culture, and place of resident residence, education, and so on. They were referring to developing countries the competence that allows 
any individual to effectively respond to new private events and changes in the economic environment. In the modern world is currently playing the role of gateway graduate education, gain capabilities, and process the necessary information or handle any other everyday life problems. The survey results show the grade of knowledge and expertise in this area is not extraordinary. In addition to having the right to access information is transparent's, it also has the responsibility and good responsibility. Although the types of institutions interested in education in this area, the greatness right choice between a wide range of new products and services filled by providers as well as their application in practice. It depends on a large extent on consumer motivation. This is the only way to improve financially.

Lusardi et al. (2014), Berry et al. (2018), posit that financial literacy comprised of a total ability and knowledge of finance, owned by a person who manages or uses some money for a better life and aims to achieve financial well being. Financial literacy has a comprehensive and in-depth understanding of personal or family finances, and decision-making of the family. As revealed by recent empirical work focuses on the analysis of financial education interventions for the youth and adults (Brown et al., 2016; Fernandes et al., (2014), Miller et al., (2015), and Kaiser \& Menkhoff (2016) study for meta-studies on financial education programs.

Financial literacy has a crucial role to determine the SMEs' success level business performance. The understanding and capabilities of financial management become important to apply for business finance performance. The knowledge of financial literacy is important to financial literacy education indispensable for business performance. It will ultimately boil down to a regional and economic development state. Understanding and intelligence of financial literacy are crucial to managing SME's finances and good performance. Knowledge of financial literacy is currently increasing. Good financial intelligence needed in the community for the creation of a society the intelligent community in making decision accuracy. Good financial management will save the life of the community itself. The financial community will positively impact the improvement of the economy.

\subsection{Religiosity}

Religiosity refers to the religious aspects of the individual. Religiosity identified with diversity. Religiosity is interpreted as how much knowledge, how to learn beliefs, how of worship and conventions, how deep a passion for religious beliefs (Mathras et al., 2016; Mansour \& Diab 2016; Suhartanto et al., 2018). For a Moslem, religiosity can be known how far the knowledge, beliefs, implementation, and the religion of Islam. Religiosity not only manifested in worship but also do other activities that are driven based on religion. Not only from the visible and collective activities but also activities that do not appear or occur silently. Therefore, a person's religiosity will cover various sides or dimensions. Understanding of religiosity based on the dimensions is discovered. According to Ancok \& Suroso (2008) religiosity is how far the knowledge, how sturdy of faith, how diligent the implementation of worship a person's professed religion. It can be concluded that religiosity is a depth of religious passion a person and a belief in the existence of God by obeying the commandments and avoiding his prohibition from the heart and the whole body. It is not just adhering to the visible and eye-view, but also the embodiment of behavior of everyday life that does not seem.

According to Ancok \& Suroso (2008) religiosity are a system, values, beliefs, and the behavior of institution systems, all of which centered on issues that we appreciate as the most meaningful. Religiosity as a religious commitment (which associated with the religion or belief of faith), that can be seen through the activity or behavior the individual concerned with religion or the conviction of faith that embraced. Religiosity is living up to the religious or depth the confidence expressed by conduct daily worship, pray, and reading the scriptures. Religiosity manifested in the various sides of life in the form of activity that looks and can be seen by the eye, as well as activity. Religiosity according to Ancok \& Suroso (2008) has the five dimensions, namely: (1) religious beliefs (2) religious practices, (3) the feeling of diversity or religious feeling, (4) religious knowledge, and (5) religious effect.

A statement from the subject reveals that the role of religiosity was able to reduce the potential for the crime of aggression such as the following, every day there is a problem but it feels different when fitting the fasting month. We can remember so feel more patient. The subject perceives the presence of a stressor then attempts to do pray, worship, or conduct other religious rituals. The religious attitude on the 
subject can feel closeness with God. Religiosity makes the people avoid conduct deliberately hurt someone else or a demeanor criminal aggressiveness. There is a theory that can be concluded that the existence of high religiosity on security apparatus will help drive security apparatus to live up to its role in the discharge of his duty. Worship interprets life in the sight of his Lord. Religious norms of society Indonesia felt very strong. Religiosity can be therapeutic to reduce the potential for the crime of aggression. Religion plays a role in the lives of individuals.

\subsection{Hypothesis Development-Financial Literacy and Business Performance}

The higher level of financial literacy business owners will affect on business performance of the SME. Good financial literacy can improve management for good business performance business. The structure of the plan work, the existence of sales growth, and fixed costs can anticipate production when demand increases. Dahmen and Rodriguez (2014) stated that the required financial literacy level for understanding trade mainly for the preparation of the financial statements to funding his business. A business owner, it is important to understand financial knowledge to have a better performance of the company.

Previous research by Dahmen \& Rodríguez (2014) found that there is a relationship between financial literacy and entrepreneurs' business performance. This relationship logically applies to companies with financial literacy that will be able to strategically identify and respond to changes in the business climate, economy, and finance. The decisions taken will create innovative solutions and directional well to improved business performance and sustainability efforts.

According to Bodvarsson \& Walker (2004) and Lyons (2004) bad financial management can affect performance, mental and physical well-being. Aribawa (2016) and Rahayu \& Musdholifah (2017) use structural equation models to analyze data. The results posit that there is a financial literacy influence on the performance and sustainability of SMEs in Central Java. The presence of good financial literacy expected SMEs will have the ability to make decisions and the right financial management to increase the performance and sustainability of SMEs. With a high level of financial literacy, the entrepreneur will further optimize its business performance with a better and more cautious operation. It will be easier in the management of its business when employers have good financial knowledge capabilities. The resulting business decision and financial management will lead to the development SME sector with good financial literacy skills. This leads to the following hypothesis:

\section{H1: There are positive effects of financial literacy on business performance}

\subsection{Hypothesis Development - Religiosity and Business Performance.}

Agyei (2018) implies that religious beliefs influence financial decisions that impact firm performance differently. There is a relationship between religiosity and SMEs' performance. Trigrunoho (2017) stated that the Sharia Bank in the region with a high religiosity index showed better profitability/performance and stability; also found that religiosity has a stronger effect. Hilary et al (2008) found a positive relationship between individual religiosity and risk aversion. The researcher also found that firms' located countries with higher levels of religiosity have low-risk experience and good business performance. Hess (2012) examines the impact of religiosity on financial decisions and business performance. He found that religious individuals have significantly higher credit scores and religion has a strong influence on their financial decisions and business performance. Therefore, from the above argument the study proposes the following hypothesis:

H2: There are positive effects of religiosity on business performance

The moderation religiosity values in the financial literacy SMEs with performance relationship does not only strengthen the relationship but also leads to the observation of a significant positive relationship between religiosity and SMEs performance. Religiosity moderates the relationship between financial literacy and firm growth/business performance

\subsection{Religiosity Moderates Financial Literacy and Business Performance}

A moderator variable is a variable that affects either weakens or strengthens the relationship between the independent variable to the dependent. In this case, the moderating variable is being religiosity. Rahim (2015) conducted a study about psychological factors influencing gender and the grade of 
Islam financial literacy. The research results gain a significant relationship among psychological factors, learned helplessness, religiosity, gender on Islamic financial literacy.

Empowering and encouraging entrepreneurial activities (Gümüsay, 2015) Islam posits that its followers to do business and enjoy the benefits. Islam emphasizes the importance of being an excellent trader by having a balanced life. Muslim entrepreneurs, to be honest and trustworthy on this earth (de Run et al., 2010). Islam teaches its people to learn and add knowledge as well as skills of finance. The more one learns and digs science increasingly; it is more likely to strengthen the relations between financial literacy on business performance. Religion serves as a means of screening financial literacy, thereby directly affecting business performance.

Many aspects can determine the choice of types of financial companies, such as Islamic education, financial literacy, banking services technology development, branch locations, etc. Religiosity can be only one factor. (Mollah \& Zaman, 2015) studied the influence of governance structures in Sharia Bank. They concluded that the governance structure of Islamic banks permits them to take higher risks/financial literacy and get better business performance because of product complexity and transaction mechanisms. (Mollah \& Zaman, 2015) found a positive contribution Sharia Bank board with disciplinary and regulatory mechanisms to be more efficient. Trigrunoho (2017) stated that the Sharia Bank in the region with a high religiosity index showed better profitability/performance and stability. They also found that religiosity has a stronger effect on the Islamic Bank that operates outside Java Island. Possible reasons because Java Island is characterized by more inhabitants, better education, and good economic conditions in financial literacy. Some Sharia banks are higher than those outside Java. They have better efficiency to deal with the pressure of competition. It can be concluded that degradation strengthens the influence of financial literacy on business performance.

According to Agyei (2018) religious beliefs affect firm performance differently. This cultureperformance influenced by the predominant firm decision and religion. Based on key culture-led firm decisions (capital structure, the quest for profit, corporate governance, and innovation) that the effect of religion strengthens financial literacy on performance. There is a relationship between religiosity and SME performance. The moderation of religious values in the financial literacy SMEs with performance relationship does not only strengthen the relationship but also leads to the observation of a significant positive relationship between religiosity and SME's performance. Religiosity moderates the relationship between financial literacy and firm growth/business performance. The preceding argument leads to the following hypothesis:

H3: The effect of financial literacy on business performance is influenced by religiosity, such that higher religiosity may strengthen the effect of financial literacy on business performance.

\section{Methodology of research}

\subsection{Population and Sample}

The population in this research was small-medium enterprises that are located in Sumatera, Indonesia. The sample was taken from the population. The data were obtained from a questionnaire survey. The questionnaires were disseminated to SMEs owners in Sumatera, Indonesia. According to Sekaran (2018), a minimum sample of 384 respondents is sufficient for 1,000,000 population. The categories under the definition of SMEs including micro company and small company industry with one proprietary are included for this research. The data were analyzed using a structural equation model (SEM), based on a partial least square (PLS).

\subsection{Measurements}

Previous studies on business performance, financial literacy, and religiosity have used the questionnaires for data collection and the studies are presented in Table 1. 
Table 1. Research design

\begin{tabular}{lll}
\hline Variables & Instruments & Measurement \\
\hline 1. Business performance & Questionnaires & $\begin{array}{l}\text { Pellissier et al., (2004), Aribawa, (2016); Rahayu and Musdholifah, } \\
\text { (2017), Yusitha, (2017). }\end{array}$ \\
2. Financial Literacy & Questionnaires & $\begin{array}{l}\text { Chen and Volpe (1998), Sabri et al, (2010); Nababan and Sadalia, } \\
\text { (2012); Rahayu and Musdholifah, (2017), Yusitha, (2017) }\end{array}$ \\
3. Religiosity & Questionnaires & Adawiyah and Pramuka, (2017); Pramono and Adawiyah, (2018)
\end{tabular}

\section{Results and Discussions}

\subsection{Descriptive}

The low questionnaire response is consistent with other studies, such as Tse (2017) on response rates for the study the $7.0 \%$ Nevertheless, the researcher believes that the rate is sufficient since it fulfills the minimum requirement of $14 \%$ as suggested by Saunder, Lewis, and Thornhill (2003) for a survey-type study. According to SME Survey (2018), Over 10,000 SMEs were invited to participate. For the first time, the survey was conducted entirely electronically, presenting an opportunity to trial behavioral insights to improve response rates. Over 2,000 respondents completed the survey, a response rate of 20 percent, providing a robust basis for reporting and extrapolating results. rates. (Pielsticker \& Hiebl, 2020) in his paper, he addresses these voidsand finds that the average response rates of family business survey studies published in seven prominent outlets amount to $21 \%$.

In this study, the questionnaires were distributed to SMEs owners in Sumatera, Indonesia. The total returned questionnaires were 387. Profiles of the respondents are summarized in Table 2.

Table 2. Respondent Profiles ( $\mathrm{N}=387$ )

\begin{tabular}{llll}
\hline Variables & & Frequency & Percentage (\%) \\
\hline 1. Distribution of sectors sample & Water Refill & 6 & 1.55 \\
& The Stationery & 6 & 1.55 \\
& Beauty Business & 10 & 2.58 \\
& Fashion & 75 & 19.38 \\
& Services & 8 & 2.07 \\
& Culinary & 88 & 22.74 \\
& Industry & 19 & 4.91 \\
& Agro Business & 25 & 6.46 \\
& Business Education Sector & 5 & 1.29 \\
& Business Field Technology & 5 & 1.29 \\
& Electronic Business and gadgets & 15 & 3.88 \\
& Wholesale and retail Enterprises & 50 & 12.92 \\
& Handicraft Business & 12 & 3.10 \\
& Trade & 63 & 16.28 \\
& Male & 200 & 51.68 \\
& Female & 187 & 48.32 \\
& Rp 500.000 - Rp 3.000.000 & 155 & 40.05 \\
3. Gender & Rp 3.100.000 - Rp 7.000.000 & 94 & 24.29 \\
& Rp 7.100.000 - Rp 10.000.000 & 57 & 14.73 \\
& Rp 10.100.000- Rp 13.000.000 & 45 & 11.63 \\
& >Rp 13.000.000 & 36 & 9.30 \\
& Madrasah Ibtidaiyah & 21 & 5.43 \\
& Madrasah Tsanawiyah & 49 & 12.66 \\
& Madrasah Aliyah & 46 & 11.89 \\
& Pesantren & 17 & 4.39 \\
& TPA / MDA & 254 & 65.63 \\
\hline
\end{tabular}


Profiles of the respondents are summarized in Table 2. Concerning type distribution of sectors samples the highest frequency at 88 respondents (22.74\%) culinary, followed by fashion 75 respondents $(19.38 \%)$ and wholesale and trade $63(16.28 \%)$. In terms of gender, 200 respondents $(51.68 \%)$ are men while 187 respondents (48.32\%) are women. In terms of income, the majority of the respondents earn between Rp 500.000 and $\mathrm{Rp} 3.000 .000$ are 155 respondents (40.05\%), followed by $\mathrm{Rp} 3.100 .000$ to $\mathrm{Rp}$ 7.000 .000 are 94 respondents (24.29\%). Religion formal education of TPA / MDA at 254 (65.63\%), followed by Madrasah Tsanawiyah at 49 (12.66\%).

\subsection{Validity and reliability test}

Validity test using loading factors above 0.6 (Sekaran, 2018). There are 2 invalid item questions for business performance; BP2 and BP 4. All questions for religiosity are valid. The financial literacy measurements were based on true or false questions. The numbers of the correct answers were calculated and divided with all the correct answers by the respondents. The answers were then divided into two different groups. The groups were categorized as follows: true $=1$, and false $=0$. The validity figure 1 as follows:

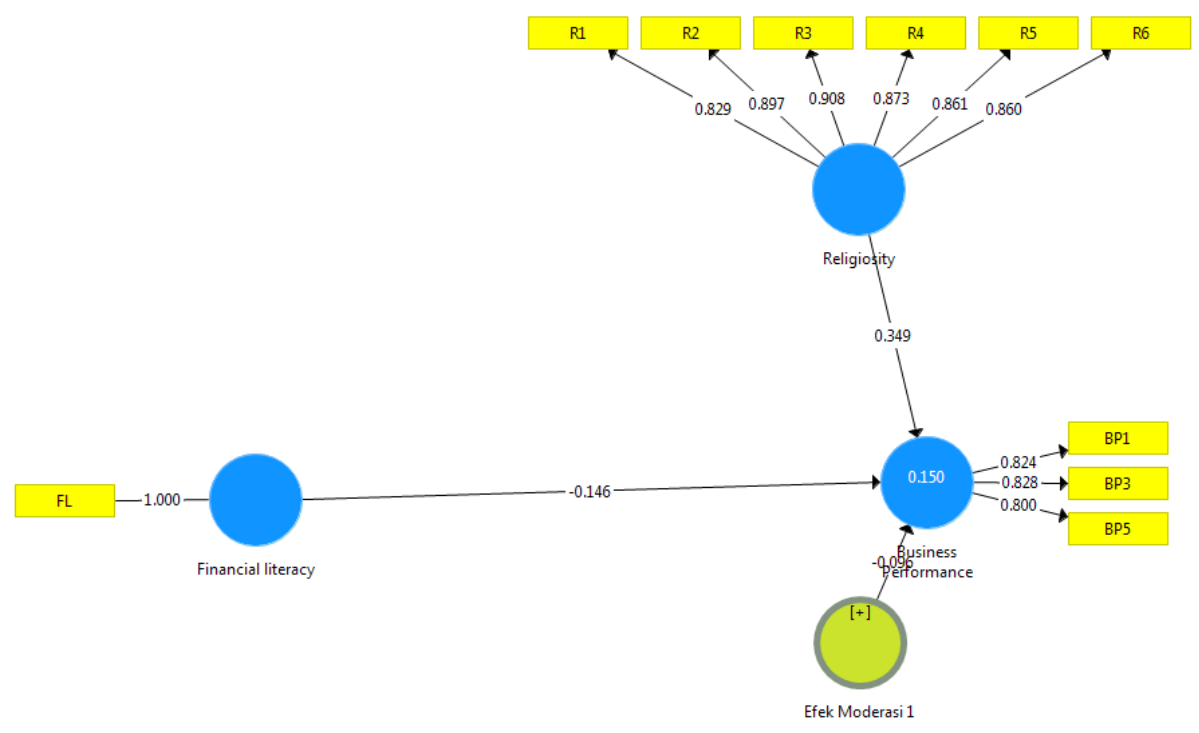

Figure 1. Validity test

The idea behind this method is that the same items in the questionnaire measure similar constructs and the item should be highly correlated. The most popular test is Cronbach's coefficient alpha. The range Cronbach alpha is from 0 to 1 . When the coefficient is bellow 0.7 , reliability is considered good (Sekaran, 2018). Table 3 show Cronbach alpha values for the constructs of business performance and religiosity.

Table 3. Cronbach alpha

\begin{tabular}{lcc}
\hline \multicolumn{1}{c}{ Constuct } & Number of question & Cronbach's alpha \\
\hline Business Performance (BP) & 4 & 0.762 \\
Religiosity (R) & 6 & 0.895 \\
\hline
\end{tabular}

\subsection{Descriptive Statistic of Business Performance and Religiosity}

Table 4 provides descriptive statistics results on business performance. The result shows the item "I have the ability to anticipate the sum of production when demand increases" (BP5) rated the highest, with a mean of 4.075. The statement "the existence of sales growth for my business" (BP3) rated as the second highest with a mean of 4.028. Meanwhile, the item "The work I planned to go well and create a profit" (BP1) rated the lowest with a mean of 3.845 . 
Table 4. Descriptif Statistic Business Performance for SMEs ( $N=387$ )

\begin{tabular}{cccccc}
\hline Variables & Denoted by & Mean & Std Deviation & Min & Max \\
\hline Business Performance & BP & & & & \\
BP1 & & 3.845 & 0.827 & 1 & 5 \\
BP3 & & 4.028 & 0.792 & 1 & 5 \\
BP5 & 4.075 & 0.710 & 1 & 5 \\
\hline
\end{tabular}

Table 5 provides the descriptive statistics results on religiosity. The result shows that "I believe working is a worship" (R2) rated the highest, with a mean of 4.491. The statement "I believe that working hard is a part of faith" (R4) rated as the second highest with a mean of 4.470. Meanwhile "Islam makes me able to adapt the condition at work" (R1) rated the lowest with mean of 4.289.

Table 5. Descriptif Statistic Religiosity for SME ( $N=387)$

\begin{tabular}{lccccc}
\hline \multicolumn{1}{c}{ Variables } & Denoted by & Mean & Std Deviation & Min & Max \\
\hline Parents' Experience & $\mathrm{R}$ & & & & \\
R1 & & 4.289 & 0.853 & 1 & 5 \\
R2 & & 4.491 & 0.846 & 1 & 5 \\
R3 & & 4.388 & 0.853 & 1 & 5 \\
R4 & & 4.470 & 0.811 & 1 & 5 \\
R6 & & 4.331 & 0.838 & 1 & 5 \\
\hline
\end{tabular}

R5 excludes and not tested because it has high collinearity at 5.367. Collinearity good if it has VIF < five.

\subsection{Result of Hypothesis}

Figure 2 and Table 6 show that financial literacy has a significant relationship to business performance. The coefficient of financial literacy is significant at $1 \%$ level of significance. In addition, religiosity related to business performance at a $1 \%$ level of significance and religiosity strengthens financial literacy related to business performance at a $10 \%$ level of significance.

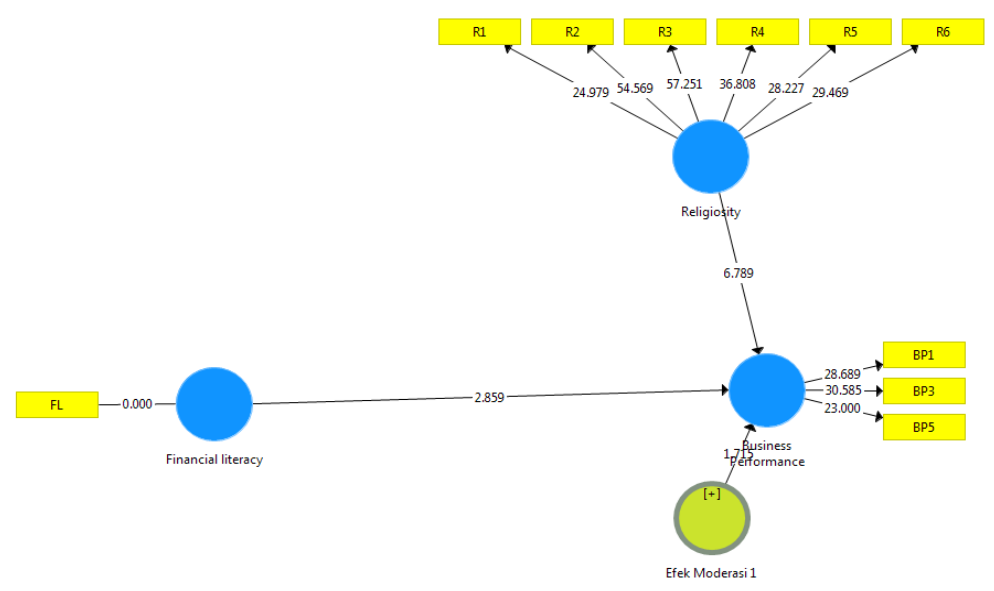

Figure 2. Hypotheses test

Table 6. Model Summary Statistics of religiosity as moderating between financial literacy and business performance

\begin{tabular}{|c|c|c|c|c|}
\hline \multicolumn{5}{|l|}{ Variable } \\
\hline Financial Literacy & $\rightarrow$ busine & lance & $0.004 * *$ & $\mathrm{H} 1$ accepted at $\alpha 1 \%$ \\
\hline Religiosity & $\rightarrow$ busine & lance & $0.000 *$ & $\mathrm{H} 2$ accepted at $\alpha 1 \%$ \\
\hline Efek moderasi & $->$ busine & lance & $0.087^{*}$ & $\mathrm{H} 3$ accepted at $\alpha 10 \%$ \\
\hline$R^{2}$ & 0.156 & $\rightarrow$ & 0.160 & \\
\hline $\mathrm{R}^{2}$ adjusted & 0.024 & $\rightarrow$ & 0.153 & \\
\hline
\end{tabular}

$* * *, * *, *$ indicates that regression analysis is statistically significant at $1 \%, 5 \%$, and $10 \%$, respectively 
Objective hypothesis 1 is to investigate the relationship between financial literacy on business performance. There are positive effects of financial literacy on business performance is accepted. Furthermore, hypothesis 2 supported, there is a relationship between religiosity with a business performance at significance 1\%. Hypothesis 3 find the effect of financial literacy on business performance is influenced by religiosity, such that higher religiosity may strengthen the effect of financial literacy on business performance is also supported.

There is a moderating effect religiosity between financial literacy and business performance with $0.030 \mathrm{p}$-values. This is quasi moderating because religiosity also influences business performance $R^{2}$ increased from 0.156 to $0.160, R^{2}$ adjusted from 0.024 to 0.153 Financial literacy to strengthen financial literacy and business performance.

\section{Discussions and conclusions}

The study also find positive significant effects of financial literacy on business performance. Financial literacy will affect business performance. Financial literacy is part of basic human needs in achieving good business performance. Some researches review financial literacy to improve the well-being of society. The studies are conducted by Lusardi \& Mitchell (2008)The financial literacy is significant to maintain or achieve financial well-being for retirement. Nawi \& Hussin (2020) find the direct effect of Financial Planning/ financial literacy with the Financial Wellbeing/performance, there is evidence to accept hypotheses as the p-values are more than 0.05. Trigrunoho et al. (2017) stated that the Sharia Bank in the region with a high religiosity index showed better profitability/performance and stability. He also found that religiosity has a stronger effect on the Islamic Bank that operates outside the Java island. It can be concluded that degradation strengthens the influence of financial literacy on business performance.

Weaver \& Agle (2002) examines the relationship between religiosity and ethical behavior in financial literacy and business performance. The researcher found that religiosity affects the business performance of people. Researchers found that those who have religious beliefs are more likely to save and have low investment in risky assets. Hilary et al (2008) found a positive relationship between individual religiosity and risk aversion. The researcher also found that firms' located countries with higher levels of religiosity have low-risk experience and good business performance. Keller et al (2007) learn the relationship between religiosity, financial literacy, and business performance. Researchers found that religiosity is a dependency of absolute power that teaches true and false. God has absolute strength. Researchers have also found the result that religiosity has a strong influence on the moral supervision of both genders.

In this moderation analysis, religiosity represents the moderator variable. This is similar to Trigrunoho et all (2017) stated that the Sharia Bank in the region with a high religiosity index showed better profitability/performance and stability, also found that religiosity has a stronger effect. Agyei (2018) states that religious beliefs influence financial decisions and firm performance. The moderation religiosity values in the financial literacy SMEs with performance relationships strengthen the relationship between financial literacy and business performance/firm growth. It also leads to the observation of a significant positive relationship between religiosity and SMEs performance.

This study supported by Adi \& Adawiyah (2018) states that religiosity as a moderating variable among environmental orientation and marketing practices, they found that a moderate religiosity relationship between environmental orientation and marketing practices. It supports religiosity that moderates the relationship between environmental and marketing orientation. In addition, marketing has a positive effect on business operations and performance. An understanding of the importance of environmental awareness and environmentally friendly marketing practices to achieve the company's operational and business performance. Masruroh (2015) also tests a moderating variable religiosity. The results of statistical tests in mind that variable disposable income after being moderated by influential religiosity in variables significantly to saving interest student STAIN Salatiga. The disposable income variable has moderated the value $T$ count of 6.101 and significance value 0.000 variable meaning. Disposable income may affect the interest of saving if moderated by variable levels of religiosity.

Shu et al. (2012) examined that researchers found that religious beliefs influence a person's risk in the conduct and investing decisions of professional fund managers. Hess (2010) examines the impact of religiosity on financial decisions and business performance. He found that religious individuals have 
significantly higher credit scores and religion has a strong influence on their financial decisions and business performance. Other studies that put religiosity as moderation is variable. According to Basri (2014) his study researching the influence of the ethics of money against the tax fraud/financial moderated by religiosity. The results of the analysis show that religiosity intrinsic ethical money relationship with moderate fraud tax (tax evasion). The results showed that intrinsic religiosity has a positive impact on the behavior of tax cheating. The higher the intrinsic religiosity, the higher a person's ethics thus lowering tax cheating. Ethical money interaction with low religiosity is causing an increasingly unethical behavior. The study results are consistent with Lau et al. (2013) which indicates that intrinsic religiosity moderate relationship ethics of money and tax fraud.

\section{References}

1. Adawiyah, W. R., Pramuka, B. A. (2017). Scaling the notion of Islamic spirituality in the workplace, Journal of Management Development, Vol. 36 No. 7, pp. 877-898.

2. Adi, P, H., Adawiyah, W. R. (2018). The impact of religiosity, environmental marketing orientation, and practices on performance: A case of Muslim entrepreneurs in Indonesia, Journal of Islamic Marketing, https://doi.org/10.1108/JIMA-09-2016-0067

3. Agyei, S. K., (2018). Culture, financial literacy, and SME performance in Ghana, Cogent Economics \& Finance (2018), 6: 1463813, https://doi.org/10.1080/23322039.2018.1463813

4. Alhadab, M. M., \& Own, B. A. (2017). Earnings Management and Banks Performance: Evidence from Europe. International Journal of Academic Research in Accounting, Finance and Management Sciences, 7(4), 134-145. https://doi.org/10.6007/ijarafms/v7-i4/3444

5. Djamaludin, A., Suroso, F. N., Cetakan, VII. (2008). Psikologi Islami: Solusi Islam atas ProblemProblem Psikologi. Yogyakarta: Pustaka Pelajar.

6. Anggraeni, B. D. (2015). Pengaruh Tingkat Literasi Keuangan Pemilik Usaha Terhadap Pengelolaan Keuangan. Studi Kasus: UMKM Depok. Jurnal Vokasi Indonesia, Vol.3 No.1, 22-30

7. Ani, C. G. P., Kelmara, M. V., Wesley, M.-Da-Silva. (2016) Development of a financial literacy model for university students, Management Research Review, 39(3), 356-376, https://doi.org/10.1108/ MRR-06-2014-0143

8. Aribawa, D. (2016). Pengaruh literasi keuangan terhadap kinerja dan keberlangsungan umkm di jawa tengah, Jurnal SiasatBisnis Vol. 20 No. 1, Januari 2016.

9. Basri, M. (2014), Efek Moderasi Religuisitas Dan Gender Terhadap Hubungan Etika Uang ( Money Ethics) Dan Kecurangan Pajak (Tax Evasion), SNA 17 Mataram, Lombok Universitas Mataram

10.Berry, J., Karlan, D., Pradhan, M. (2018).The impact of financial education for youth in Ghana, World Development 102 (2018) 71-89.

11.Bodvarsson, O. B., \& Walker, R. L. (2004). Do parental cash transfers weaken performance in college? Economics of Education Review, 23(5), 483-495.

12.Boehnke, M., Pokharel, S., Nyberg, E., \& Clark, T. (2018). Financial education for radiology residents: Significant improvement in measured financial literacy after a targeted intervention. Journal of the American College of Radiology, 15(1), 97-99.

13.BPS (Badan Pusat Statistik). (2015), Statistik Indonesia

14.Brown, S., \&Taylor, K. (2016). Early influences on saving behavior: Analysis of British panel data Journal of Banking \& Finance 62 (2016) 1-14.

15.Budiharjo, R. (2019). Effect Of Environmental Performance And Corporate Governance Structure On Financial Performance. International Journal of Academic Research in Accounting, Finance and Management Sciences, 9(2), 11-22. https://doi.org/10.6007/IJARAFMS/v9-i2/6021

16.Chen, H., \& Volpe, R. P. (1998), An Analysis of Financial literacy among college students. Financial Services Review, 7(1), 107-128.

17. Darwish, S. (2014). The Role of Universities in Developing Small and Medium Enterprises (SMEs): Future Challenges for Bahrain. International Business and Management, 8(2), 70-77.

18.Dahmen, P., dan Rodriguez, E. (20140. Financial Literacy and the Success of Small Businesses: An Observation from a Small Business Development Center. International Journal Of Numeracy, Vol.7, 1-12. 
19.De Run, E., Butt, M., Fam, K., and Jong, T. (2010), "Attitudes towards offensive advertising: Malaysian Muslims' view", Journal of Islamic Marketing, Vol. 1 No. 1, pp. 25-36.

20.Enterprise Survey (2015). Indonesia

21.Fernandes, D., Lynch Jr, J. G., and Netemeyer, R. G. (2014). Financial literacy, financial Education, And Downstream Financial Behaviors. Management Science, 60(8),. 1861- 1883.

22.Grohmann, A., Kouwenberg, R., \& Menkhoff, L. (2015). Childhood roots of financial literacy. Journal of Economic Psychology, 51(September), 114-133. doi.org/10.1016/j.joep.2015.09.002

23.Gümüsay, A. A. (2015), "Entrepreneurship from an Islamic perspective", Journal of Business Ethics, Vol. 130 No. 1, pp. 199-208.

24.Halamka, R., Teplý, P. (2017). The effect of ethics on banks' financial Performance, Prague Economic Papers, 2017, 26(3), 330-344, https://doi.org/10.18267/j.pep.609

25.Harash, E., Al-timimi, S., \& Alsaadi, J. (2014). The Influence of Finance on Performance of Small and Medium Enterprises (SMEs). International Journal of Engineering and Innovative Technology, 4(3), 161167. https://doi.org/10.12735/jbm.v3i4p48

26. Hess, D. W. (2012). The impact of religiosity on personal financial decisions. Journal of Religion and Society, Vol. 14

27.Jappelli, T., and Mario, P. (2011). Investment in financial knowledge and saving decisions. CSEF Working Paper 272, University of Salerno.

28.Jao, R., Hamzah, D., Laba, R. A., \& Mediaty. (2020). Financial Performance, Reputation, and Firm Value: Empirical Evidence of Non-financial Companies Listed in Indonesia Stock Exchange. International Journal of Academic Research in Accounting, 10(1), 117-124. https://doi.org/10.6007/ IJARAFMS/v10i1/7007

29. Kaiser, T., and Menkhoff, L. (2016). Does financial education impact financial behavior, and if so, when?. Working Paper.

30.Kukuh, A., Waspodo, B., \& Aeni, N. (2010). Sistem Informasi Penerimaan dan Penyaluran Zakat dengan Distribusi Konsumtif Dan Produktif ( Studi Kasus : Baitul Maal Wat Taamwil Masjid Al-Azhar Cabang Ciledug ). 3(2), 1-12.

31.Lau, T. C., Choe, K. L., \& Tan, L. P. (2013). The moderating effect of religiosity in the relationship between money ethics and tax evasion. Asian Social Science, 9(11), 213-220.

32.Lusardi, Annamaria \& Olivia, S. M. (2008). Planning and financial literacy: How do women fare? American Economic Review, 98(2), 413-417.

33.Lusardi, A., \& Mitchell, O. S. (2014). The economic importance of financial literacy : Theory and evidence. 52 (1). 5-44.

34.Lyons, A. (2004), A profile of financially at-risk college students, journal of consumer affairs, 38 (1), 56-80.

35.Mantok, S., Sekhon, H., Kaur, G. S., Jones, P. (2019), Entrepreneurial orientation and the mediating role of organizational learning amongst Indian S-SMEs, Emerald www.emeraldinsight.com, https://doi.org/ 10.1108/JSBED-07-2018

36.Mansour, I. H. F., and Diab, D. A. (2016). The relationship between celebrities' credibility and advertising effectiveness: The mediation role of religiosity. Journal of Islamic Marketing 7 (2): 148-166. DOI: 10.1108/MRR-09-2015-0216.

37.Mathras, D., Cohen, A. B., Mandel, N., \& Mick, D. G. (2016), The effects of religion on consumer behavior: A conceptual framework and research agenda, Journal of Consumer Psychology, Vol. 26, pp. 298311.

38.Mihalcová, B; Csikósová, A; Antošová, M, (2014). Financial literacy - the urgent need today, Procedia - Social and Behavioral Sciences 109 (2014) $317-321$

39.Miller, M., Reichelstein, J., Salas, C., and Zia, B. (2015). Can you help someone become financially capable? A Meta-Analysis Of The Literature. World Bank Research Observer,30(2), pp. 220-246.

40.Mollah, S., \& Zaman, M. (2015). Shari'ah supervision, corporate governance, and performance: Conventional vs. Islamic banks. Journal of Banking and Finance, 58, 418-435. https://doi.org/10.1016/ j.jbankfin.2015.04.030 
41.Muraga, K. P., dan John, N. (2015). Effects of financial literacy on business performance of youthled enterprises: a case of equity group foundation training program in Kiambu county. International Journal of Social Sciences Management and Entrepreneurship. 2(1) 218-231

42.Mutegi, H. K., Njeru, P. W., dan Ongesa, N. T. (2015). Financial Literacy And Its Impact On Loan Repayment By Small And Medium Entrepreneurs. International Journal of Economics, Commerce and Management, Vol. 3( Issue 3), 1-28.

43.Nababan, D., \& Sadalia, I. (2012). Analisis personal financial literacy dan financial behavior mahasiswa strata I Fakultas Ekonomi Universitas Sumatera Utara. http://repository.usu.ac.id/ handle/123456789/34557.

44.Nawi, H. M., \& Hussin, H. S. (2020). A Good Cop is Never Cold or Hungry: Antecedents and Consequences of Financial Literacy among Members of the Royal Malaysia Police. 10(1), 270-289. https://doi.org/10.6007/IJARAFMS/v10-i1/7194

45.Nizar, S., and Marzouki, R. (2015).Consumer attitudes and purchase intentions toward Islamic banks: the influence of religiosity, International Journal of Bank Marketing, Vol. 33, pp. 143-161.

46.OECD, (2017), Students experience with money and their performance in financial literacy, PSA 2015 Result, (Volume IV: Students' financial literacy

47.Pellissier, R, (2014). Measuring business performance: A case study, https://www.researchgate. net/publication/228548112

48.Forum, P. (2017). The future of world religions: population growth projection, 2010 2050, available at www.pewforum.org/2015/04/02/religious-projections-20102050

49.Pielsticker, D. I., \& Hiebl, M. R. W. (2020). Survey response rates in family business research. European Management Review, 17(1), 327-346. https://doi.org/10.1111/emre.12375

50.Pramono, H. A., Adawiyah, W. R. (2018). The impact of religiosity, environmental marketing orientation and practices on performance: A case of Muslim entrepreneurs in Indonesia, Journal of Islamic Marketing, https://doi.org/10.1108/JIMA-09-2016-0067

51.Puschmann, T. (2017). Fintech, Business and Information Systems Engineering 59(1):69-76 DOI 10.1007/s12599-017-0464-6

52.Michal, P., Mihalcová, B. (2014). Financial literacy of Slovak universities' students, Business Systems Review, ISSN: 2280-3866 Volume 3, Issue 1 January-June 2014

53.Rahayu, A. P., Musdholifah. (2017). Pengaruh literasi keuangan terhadap kinerja dan keberlanjutan umkm di kota Surabaya. Jurnal IImu Manajemen, Volume 5 Nomor 3- Jurusan Manajemen Fakultas Ekonomi Universitas Negeri Surabaya.

54. Rahim, A. (2015). Psychological factors and gender influencing the level of Islamic financial literacy Al-Amwal, Volume 10, No. 1 Tahun 2018 DOI : 10.24235/amwal.v10i1.2837.

55.Rapih, S. (2016). Pendidikan literasi keuangan pada anak: mengapa dan bagaimana? Scholaria, Vol. 6 No. 2, Mei 2016: 14 - 28

56.Rosacker, K. M., \& Rosacker, R. E. (2016). An exploratory study of financial literacy training for accounting and business majors. International Journal of Management Education, 14(1), 1-7. http://doi.org/10.1016/j.ijme.2015.11.002.

57.Sabri, M. F., \& Gudmunson, C. C. (2012). Financial well-being of Malaysian college student. Asian Education and Development Studies (1) 2

58.Sahlan, A. (2011). Religiusitas perguruan tinggi: Potret tradisi keagamaan di perguruan tinggi Islam. Malang: UIN Maliki Press.

59.Sekaran, U. (2018), Research methods for business: A skill-building approach, 6th Edition, Wiley

60.Shu, T., Sulaeman, J., \& Yeung, P. E. (2012). Local religious beliefs and mutual fund risk-taking behaviors. Management Science, 58(10), 1779-1796. https://doi.org/10.1287/mnsc.1120.1525

61.Thrikawala, S. S. (2011). Impact of strategic networks for the success of SMEs in Sri Lanka. World, 1(2), 108-119.

62.Weaver, G. R., Agle, B. R. (2002), Religiosity and ethical behavior in organizations: A symbolic interactionist perspective. The Academy of Management Review Vol. 27, No. 1, pp. 77-97

63.Novi, Y. A. (2017), Pentingnya literasi keuangan bagi pengelolaan keuangan pribadi, Jurnal Nominal, Volume Vi Nomor 1, pp 11-26 